\title{
An Exciting Period for Vietnamese Prose
}

By Nguyên Ngọc

Translated by Cao Thị Như-Quỳnh and John C. Schafer

Published as "An Exciting Period for Vietnamese Prose," Journal of Vietnamese Studies 3.1 (Winter, 2008): 193-219. (C 2007 by the Regents of the University of California, Center for Southeast Asia Studies, University of California, Berkeley. Copying and permissions notice: Authorization to copy this content beyond fair use (as specified in Sections 107 and 108 of the U. S. Copyright Law) for internal or personal use, or the internal or personal use of specific clients, is granted by the Regents of the University of California on behalf of the Center for Southeast Asia Studies, University of California, Berkeley, for libraries and other users, provided that they are registered with and pay the specified fee via Rightslink ${ }^{\circledR}$ service on Caliber (http://caliber.ucpress.net/) or AnthroSource (http://www.anthrosource.net) or directly with the Copyright Clearance Center, http://www.copyright.com.

\section{Translators' Note to Nguyên Ngọc's “An Exciting Period for Vietnamese Prose.”}

Born in Đà Nẵng in 1932, Nguyên Ngọc has been a leading figure in the literary and intellectual life of Vietnam for over fifty years. He joined the Resistance after the August Revolution in 1945, when he was thirteen years, old and served as both soldier and battlefield correspondent first in the war against the French and later in the American War. He is one of a group of writers from central and southern Vietnam who, after participating in the first Indochina war against the French, were "relocated" [tập kêt $]$ to Hanoi after the Geneva Accords. When the American War began these writers were sent back to the South to continue the political and military struggle for independence. ${ }^{1}$

During both wars Nguyên Ngọc spent a great deal of time in the Central Highlands where he developed a deep affection for the ethnic minority people living in this region. His first novel, The Nation Rises Up [Đất nước đưng lên] (1955), ${ }^{2}$ describes the heroic exploits of a local guerilla leader who was a member of the Bahnar ethnic group. Two collections of short stories followed, both also set in the mountains of central Vietnam: Highland [Réo cao] (1961) and The Forest of Xa nu Trees [Rừng Xà nu]. ${ }^{3}$ In 1970 he published Land of Quảng [Đất Quảng], ${ }^{4} \mathrm{a}$ novel based on his experiences as the leader of a guerilla unit in the Đà Nẵng area in the 1960s.

The above works are all fictionalized accounts of the exploits of revolutionary heroes. Nguyên Ngọc's style can be engagingly straightforward and unpretentious, but it is still what he now calls the "old war epic style." In these works we hear distinctly that "loud heroic song" that 
Nguyên Ngọc, in the following essay, argues has become "lost and strange" in post-war Vietnam. Nguyên Ngọc was one of the first to realize that different times require different ways of writing and has worked hard to ensure that other voices are heard. After mentioning the names of some writers Nguyên Ngọc has supported (e.g., Nguyễn Huy Thiệp, Bảo Ninh, Phan Thị Vàng Anh, Nguyễn Khắc Trường,Tạ Duy Anh), Trần Đăng Khoa says: “These are talented literary figures completely different from him, with writing styles directly opposed to his own. To recognize and support talent that is completely different from oneself - that I believe is one of Nguyên Ngọc's talents. Not everyone has that talent." ${ }^{5}$

Nguyên Ngọc has promoted new ways of writing by being a courageous editor, one willing to publish experimental and politically sensitive works. After 1975 he worked in Hanoi as editor for Art and Literature of the Army [Văn Nghệ Quân Đội] and then was assistant general secretary of the Writers' Association and editor of Literature and Art [Văn Nghê]]. He held this latter position when Renovation [Đổi Mới] was being launched and oversaw the publication of works by daring new writers, including some controversial short stories by Nguyễn Huy Thiệp. He was relieved of his position as editor in 1988 when strings on writers and editors were tightened in the late 1980s (see endnotes 24 and 28) but he has continued to support younger writers through his involvement with the Writers' Association and the Nguyễn Du Institute (a training academy for writers).

As an essayist, too, Nguyên Ngọc strives to breathe new life into Vietnamese literature. The essay included here is a revised version of one included in Thoughts along the Road [Nghĩ doc đuòng] (2006). ${ }^{6}$ Other essay collections include: Scattered Thoughts Remembered and Forgotten [Tản mạn nhớ và quên] (2005) and Listening to Life [Lắng nghe cuộc sống] (2006). ${ }^{7}$

In his essays Nguyên Ngọc talks about a variety of topics, not just literature. One topic that has occupied his attention a great deal lately is education. In several essays in these collections he argues for a completely new approach to education, one designed to turn students into independent thinkers and to equip them with a broad and deep knowledge of the world. To turn his vision into reality he is spearheading the establishment of Phan Châu Trinh University in Hội An, a pilot institution that he hopes will contribute to the modernization of education in Vietnam. We get a sense for Nguyên Ngọc's concern for education — and for literature-at the close of his essay where he suggests young writers are hampered by a lack of "underlying cultural knowledge" [tiềm lục văn hóa]. "An Exciting Period for Vietnamese Prose" reflects the 
passions that have moved Nguyên Ngọc throughout his life: love for country, love for literature, and love for learning.

\section{An Exciting Period for Vietnamese Prose}

\section{By Nguyên Ngọc}

Before talking about Vietnamese literature today, I must return briefly to the immediately preceding period, commonly referred to as the period of Renovation literature. This was a lively and important period, one which will continue to have a long-lasting and deep influence.

From 1975 and continuing for almost ten years, that is the years following the end of the war, Vietnamese literature suddenly fell into an unexpected situation: It completely lacked readers. People wrote more because the situation for writers become much more advantageous than it was during the war: There was more time, the violence and tenseness subsided, rich material had been accumulated during the long war, and internal and external communication channels were developed. But the many books printed did not sell. Readers turned away from domestic literature, preferring instead foreign works - and ancient Vietnamese literature.

In the beginning writers were puzzled but gradually they recognized the cause: Life had changed a great deal but the literature being produced had not.

Only a few years after the war people recognized this contradiction: Life in peacetime was much more complicated than it was during the war. War is violent but simple. In war all relationships between people and society are gathered and reduced to one: life and death. People have to live in an abnormal way. Abnormal can mean noble. At the same time, however, it involves the suppression of many ordinary — but also rich and complicated - human relationships. The abnormality of war pushes these relationships aside. In war once you have determined the problem of life and death then you can live easily. In war, strangely, society is also purer, "more secure" [an toàn hon] in terms of morality. The fire of war burns away the narrow-mindedness and complications of everyday life. Peace is completely different. In peace one confronts again the ordinariness of everyday life. Ordinary but eternal. All the complications that were hidden during the war now arise and surround one every minute of the day, no matter where one is. If during the war there was only one question, live or die, now innumerable questions of all kinds and shapes rise up from the depths of society. These questions, which accumulated silently during long and complicated historical processes, are now 
displayed for all to see. But when people search after literature hoping to find in it some comfort, some shared confidences, they hear, just as before, the same loud heroic song, a song that now has become lost and strange. No one should be surprised that people have reacted with indifference to a literature that reveals no understanding of the "common" [tầm thuoòng] and "petty" [vụn vặt] but pressing worries that they face every day.

It did not take writers long to recognize this discrepancy between literature and life because they too were members of this society, they too were confronted with a host of new questions about life in peacetime. However, being able to recognize a new reality is one thing; changing one's way of writing to accommodate it is another. According to Roland Barthes, "Words have a second memory that continues hidden within new meanings — an obstinate vestige remaining from all the ways I myself have written - that drowns out the present voice of the words I am using." 8 Writers know the new reality but are so "habitualized" [quen thói] to the old way of writing, to the old war epic style, ${ }^{9}$ that when a writer tries to speak about the new reality that "obstinate vestige remaining from all his old ways of writing" prevents his present words from capturing the new reality; instead, they slip off it like water poured on the leaf of a taro plant. As we all know, there is nothing harder for writers than changing the way they write. And when they don't yet have a new way of writing, then literature also has no new content. Writers keep acting like deaf mutes or dullards.

This situation continued until the mid 1980s. At that time Literature and Art, the official weekly journal of the Vietnam Writers' Association, which specialized in publishing new works by in-country writers, had so few readers it suffered heavy losses. It lacked funds to buy paper and pay the printer. The general editor announced that the journal was closing down and that publication would be suspended for four successive issues. This was the situation that prevailed when I was appointed general editor of Literature and Art. The first thing I did was to search through a pile of old submissions that the editorial board had rejected. In the process I discovered a short story by a writer I had never heard of: "The General Retires" [Tướng về hưu] by Nguyễn Huy Thiệp. ${ }^{10}$ This story had lain there for half a year. The former general editor had set it aside because he advocated a policy of "maximizing the journal's margin of security," which entailed not coming too near the burning issues of life. We advocated a completely different policy. A speech given on behalf of our editorial board at a ceremony commemorating the journal's fortieth year of operation was entitled "Facing up to Life." We began the new period for Literature and Art by publishing "The General Retires." 
In a cold, sharp-witted style, "The General Retires" displays a phenomenon never before seen in previous literature: the alarm and confusion of a war hero faced with the chaotic reality of post-war society. This work stirred up public opinion. Readers and also writers had many different opinions about it and about Nguyễn Huy Thiệp, but all writers, though they may not have said so openly, realized something very important: that they could no longer write as they had before. Although the period of epic literature full of revolutionary lyricism that existed during the war had passed, ten years later literature in the post-war period was still drifting along, powered primarily by inertia. It was necessary to fashion a new language to talk about the social and humanistic dimensions of an extremely complex new reality.

Not everyone, however, can create for him or herself the required artistic language. In the journal Literature and Art at that time some works of reportage [phóng sụ] appeared about different situations in society, particularly about the situation in the countryside. Reportage was a vibrant genre during roughly the years 1930-45 with writers like Vũ Trọng Phụng, Tam Lang, and Trọng Lang, but after 1945 it pretty much disappeared. Reportage is a mixed genre, a cross between journalism and literature. It is particularly useful in exposing and dissecting complex social realities. In the context of wartime literature, an epic literature devoted primarily to praise and to the mobilization and encouragement of cadre, it found no place to stand. What was valued during the war was the literary memoir [bút ký] which had the quality of an informal reflective essay [tùy bút], a genre in which the subjective feelings of the author were starkly revealed. The return of writers to the forgotten genre of reportage was a very smart move. At this time writers first have to be journalists. Reportage allows writers to encounter the new reality without being blocked by the fence of "literature" [belles-lettre]; it enables them to search out and forge a new artistic language. Works of reportage that appeared in Literature and Art and received a lot of attention include the following: "A Defendant's Statement" [Lời khai của bị can] and "A Person Who Knows How to Become Rich" [Người biết làm giàu] by Trần Huy Quang; "11 "The Kneeling Woman" [Người đàn bà quỳ] by Lưu Loan; "A Cry for Help from an Area of Culture” [Tiếng kêu cứu của một vùng văn hóa] by Võ Văn Trực; "13 "Sleepless Night" [Đêm trắng] by Hoàng Hữu Cát; ${ }^{14}$ and "The Night of That Day, What a Night!" [Cái đêm hôm ấy đêm gì] by Phùng Gia Lộc. ${ }^{15}$ These were the works that stirred up public opinion and quickly caused people to return to literature. The reportage genre, which had recovered so successfully, also filled literature with the new social reality, something it had greatly lacked previously. 
In the period that followed something occurred that could be considered a departure from the usual relationships among genres. Typically the memoir or non-fiction report [bút ký] (in this case, reportage) is followed by the short story. But this time something completely different took place: Instead of a movement directly from reportage to short story, there suddenly appeared an exciting period of the novel. Dozens, even hundreds of novels, appeared in a period of only a few months. Many writers who before hadn't specialized in this genre took up the writing of novels. And their works were well-received by readers. Thick novels filled up market stalls and sold quickly. The novel ascended the throne before the short story. Why? If one looks closely at their ascent, one notices that the novels of this period revealed clearly certain characteristics: They could be called novelistic reportage [tiểu thuyết-phóng sụ], a kind of extended reportage usually based directly on real and controversial social events; they had a distinct journalistic qualitytheir fictional component was small; and they openly embraced political discussion. Clearly this rise of the novel was a continuation of the reportage discussed above, a genre which writers had concluded was no longer capable of carrying the rich social content they wanted quickly to present to readers. So they switched to the novel. They also wanted to become involved, to inject their own personal opinions. Nguyễn Mạnh Tuấn's Mangrove Islands [Cù lao tràm] ${ }^{16}$ is a typical example of these works that ushered in this kind of novel. In it the author discusses a controversial issue concerning the management of agriculture, using his work to enter actively into this debate. This book is still used as a subject for debate in many regions as people struggle for a new and effective management approach in the countryside.

This flourishing period for the novel continued for five or six years, then gradually cooled off. Many novels appeared but readers did not give them the attention that they had previously. This was when the short story rose up with many excellent stories appearing. Many critics talked of a "bumper crop of short stories" [môtt vu được mùa truyện ngắn]. The arrival of this bumper crop of short stories following the novel can be explained in this way: Readers were no longer demanding long novels that exposed and "denounced" [tố cáo] social reality. In exposing and "denouncing" that reality these novels participated in the process of democratizing society. But the time had come when just exposing and denouncing were not enough. Journalism could do that much better than novelists. And even people on the street were speaking much more openly, more completely, more fiercely than writers. Readers demanded something different. People waited for writers to consider the complex changes occurring and present them with some conclusions of a profound and enduring humanistic quality. And that 
was something that the long novel of exposure was not yet able to do. One of the best novels during this period, Nguyễn Khắc Trường's Land of Many People, Many Ghosts [Mảnh đất lắm người nhiều $\mathrm{ma}],{ }^{17}$ typifies both the successes and limitations of the novel of exposure. Applying his superb understanding of the Red River Delta region, Nguyễn Khắc Trường reveals how deep rooted vestiges of feudalism combined with the prolonged imposition of unnatural administrative mechanisms, and then the newly arrived pressures of a weak market economy, created a strange and debilitating turmoil in social relations that extended even to the party leadership. In distinctive language, Nguyễn Khắc Trường presented to readers “a frightening reality prevailing in the countryside, a reality that was difficult for us to imagine." ${ }^{18}$ In that regard this work is outstanding. But after three hundred excellent pages exposing problems, come one hundred pages which we can't avoid perceiving as anything but an interminable continuation of what has come before. Most other novels [written at this time] were not any better.

A few other novels signaled somewhat different directions. For example, there was Lê Lựu's A Time Far Past [Thờ xa vắng]. 19 "A time far past” is just a clever way of speaking. Actually that time, when individuals are not only covered by a nameless collective but also refuse to look into their own hearts, is still with us. In Dương Hướng's Wharf without a Husband [Bến không chồng] ${ }^{20}$ the cry of the individual is even more strongly and mournfully buried. This novel describes a very good person, someone who all his life strove to make other people happy, but didn't dare accept a bit of personal happiness for himself, regarding it instead as a fault, even a crime. Determining the proper role of the individual, ensuring that each individual can develop freely and completely, is a big problem in Vietnamese society. Several novels touched on this social wound, but taken as a whole they treated it in a scattered and vague way. The power of the novel to generalize about society remained very weak.

Literature chose another genre to do the work that the novel was not yet able to do, a genre that by itself, as a result of its distinguishing characteristics, demands generalization: the short story.

In Vietnamese literature we can consider the present time a noteworthy one for the short story. Many excellent stories have appeared, stories which continue "the bumper crop" that appeared in the 1960s and another crop that appeared during the war. These recent stories, however, differ in some obvious ways from these earlier stories. The 1960s left us many short stories as beautiful as a poem, crystal clear, and lyrical. Short stories during the war were sturdy and solid. What stands out about these recent stories is that when you hold them in your hand 
you feel the weight of their content. There are some stories only ten pages long that are more powerful than a long novel. Neatly wrapped within the ten pages of Tạ Duy Anh's “The Broken Curse" [Bước qua lời nguyền], ${ }^{21}$ for example, one finds an entire life, the fate of a person who is both the author and also a victim of interminable social tragedies occurring at that time. Compressed within Hào Vũ's short story "The Floating Merchant" [Khách thương hồ], ${ }^{22}$ short enough to be written on one's hand (less than a thousand words), is the fate of two people searching for a little happiness later in life. Both are victims of the war but from different sides. The short stories of Phan thị Vàng Anh at first glance appear soft and faint like a breeze or a gentle, sad rainstorm, and so they are easily mistaken for the kind of stories students write. But if you read them carefully you detect conflicts, sometimes very fierce, especially those between generations, which people try to repress, as in her short story "Pantomime" [Kịch câm].

The short story has achieved this rich content precisely because the literary stages of reportage and the novel described above prepared the way for it. It had plenty of social material to sift through and distill.

The writer who stands out the most is, of course, still Nguyễn Huy Thiệp, and next to him, Phạm Thị Hoài.

A lot has been said about Nguyễn Huy Thiệp so here I will just mention a few aspects of his multifaceted ability. Nguyễn Huy Thiệp appeared during the renovation of Vietnamese literature and is the most typical manifestation of that movement. However, his approach differed from that taken by the Renovation writers mentioned above who were interested in exposing and denouncing complicated social realities. Nguyễn Huy Thiệp took a different road. Very early he began writing from many differing angles, using an approach so multifaceted it often left readers stunned. Proceeding sometimes directly, sometimes through rich refractions [khúc xa phong phú], ${ }^{23}$ sometimes decisively and fiercely — even shamelessly, sometimes fondly and poetically, he turned things upside down in order to reveal the long hidden origins of those social realities described by other writers. In the process he initiated in modern Vietnamese literature what we can call a literature of self-questioning [văn học tư vấn (author's emphasis)]. As a result a breath of new vitality spread through Vietnamese literature and from literature entered society. One can also put it this way: Drawing on his artistic sensibility, Nguyễn Huy Thiệp was able to "hear" within Vietnamese society the profound need, one growing everyday more pressing, to look at ourselves in a mirror to discover who we are. His literature is the literature that expresses that need, which strives to find the answer to that question. He has 
begun a very important shift in Vietnamese literature, a movement toward a literature that feels strongly the responsibility to function as a mirror in which the Vietnamese — and all people — can see themselves.

After many long and endless periods of opposing invaders this is really the first time the Vietnamese people have had to confront not enemies from outside but ourselves, to ask who we really are, what our history really is. (Certainly it is not by chance that among Nguyễn Huy Thiệp's extremely multifaceted short stories there is a group referred to as "the history stories."24 Actually these are stories that liberate [giải (author's emphasis)] history from the myths that have been woven around it for many lifetimes.) Now people are asking why things today are the way they are and why the certainty we had about ourselves when we were waging war no longer exists.

To self-question is to look inward. If the literature that exposes and denounces is essentially outward-looking, the literature of Nguyễn Huy Thiệp is inward-looking. One can say that this is the first time in literature that the Vietnamese people have become so decisively engaged in self-revelation. This, I submit, is the most important contribution of Nguyễn Huy Thiệp.

In addition to Nguyễn Huy Thiệp there is another short story writer who is no less insightful: Phạm Thị Hoài. In her self-questioning Phạm Thị Hoài concentrates on what she feels is the most important aspect of a society and a nationality: the elite, the intellectuals. Armed with a literary knowledge that is as sharp as a knife and with an unyielding - even sometimes impertinent - attitude, she pierces deeply the boils still being covered up by a group whose members are themselves filled with illusions. She coldly dissects these representatives of society, tears off the masks they have been wearing for a long time, and forces them to face unpleasant truths about themselves. There may be people who don't always appreciate Phạm Thị Hoài's approach, but no one can deny that this outstanding female writer is serious about her social responsibilities.

Compared to other genres, the short story has clearly progressed the furthest. Most novels have stopped at the level of description. If they do reveal some opinions concerning society, these revelations assume the form of journalistic political commentary. I say "most" because there is an exception: Bảo Ninh.

Bảo Ninh's novel The Sorrow of War [Nỗi buồn chiến tranh $]^{25}$ was the first novel to speak differently about the recent war in Vietnam. All previous works about the war considered 
it in relation to the fate of the Vietnamese people, the Vietnamese community. Bảo Ninh was the first in the modern literature of Vietnam to consider the war from the perspective of the individual person. So he saw a different war. He didn't reject the meaning of, or deny, or oppose the war described in previous works (as people who attack and denounce his novel maintain ${ }^{26}$ ). His war, however, was a different war. From the very beginning Bảo Ninh conceived art in a different way, especially the art of the novel. He understood that there are many different ways of looking at something, and that no way is more powerful than any other, no way represents the unique and absolute truth. Something can be both like this and also like that. The world, in its basic nature, is polysemantic [đa nghĩa].

This polysemantic perspective, the idea that the world, and war-including the recent war that we still regard as exceedingly sacred - are multifaceted in their meanings, permeates Bảo Ninh's novel. Read each sentence carefully and see if this is not true: Almost every sentence, even each word, conveys at least two different and contrasting meanings. "The war," he writes, "is both remembered forever and forgotten each day." Of "sorrow," he says, it is "the sorrow of surviving." Of the future of those who have just emerged from the war, of his own future, he says: "My future lies far behind me in the primitive forests of the war." Bảo Ninh was the first to move beyond the monologue of the epic and achieve the dialogue of the novel. ${ }^{27}$

On the artistic front that is the highest achievement of Renovation literature. At this point Renovation literature, which previously was only new in terms of its modern political and social ideas (which people usually wrongly refer to as "content") created for itself a new artistic language. The monologic language of the epic, as we know, is the dogmatic language of the community. The dialogic language of the novel is the democratic language of the individual. The Sorrow of War strongly affirms the role of the individual in society, the right to life, happiness, and suffering of each individual.

That was in the year 1991.

Then suddenly there was a prolonged pause, both those involved and not involved searched for an explanation.

No one says that Renovation has halted, but in literature it clearly has slowed down since 1991. From that time up to the present writers have continued to write, books have continued to be published, and literary prizes have continued to be awarded. And works that are "readable" have appeared. But there have been no new phenomena [author's emphasis], no new initiatives, 
no new Nguyễn Huy Thiệp's, or Phạm Thị Hoài's, or Bảo Ninh’s. As far as literary production is concerned, these have been, generally speaking, lean times.

Why? And within that general "leanness" [làng nhàng] can we detect any hopeful signs? And how can we "free up" [khai thông] again the natural flow of creativity?

As we have seen Renovation has featured the direct and active involvement of literature in the social process. In the history of Vietnamese literature there is nothing strange about this. Since ancient times Vietnamese literature has emphasized the tradition summed up in the saying "Literature carries doctrine" [Văn dĩ tải đạo]. In modern times the idea of "engagement" [dấn thân] and "involvement" [can $d u$ ] have not been strange concepts. This time, however, the “involvement" is different. Previously literature spoke of intense "involvement" and "engagement," sometimes even of total commitment, in order to encourage and mobilize people to follow the path of orthodoxy. Literature was a mouthpiece for orthodoxy. In this period of Renovation, however, for the first time, at least since 1945, not just one writer, or one work, but all of literature is actively involved, often very decisively involved, in presenting unorthodox positions. Literature is now involved not to approve and encourage but to criticize and condemn, to look at problems from different angles, from the level of details and parts up to the entire system.

After literature became involved in current problems, powerful and influential forces in the society quickly reciprocated and became involved with literature. The general editor of Literature and $\mathrm{Art}^{28}$ and the general editors of other magazines and journals throughout the country were replaced. A number of works were blocked in various ways at publishing houses. Either they weren't allowed to reach readers or, if already published, their distribution was forbidden. In 1991 the Writers' Association awarded prizes for three outstanding works: The Sorrow of War, Land with Many People, Many Ghosts, and Wharf without a Husband. In 1992 it was anticipated that prizes would be awarded for Tô Hoài's memoir Dusty Sand on Somebody's Footsteps [Cát bụi chân ai] ${ }^{29}$ and for the short stories of Nguyễn Huy Thiệp, but this move was thwarted by changing the selection board. The atmosphere became tense and oppressive. Recently, in an exchange with the magazine Today [Ngày Nay], the researcher Lê Ngọc Trà described the situation in this way:

Society has not yet created for the writer an environment, an atmosphere, conducive to creation. To produce a good work a writer has to be able to "come" [đến] to-even to "collide with" [dung cham] — the complicated problems and obstacles of life, those problems that no one can say for sure are right or wrong. But that requires a social atmosphere that encourages the writer and enables him or her to write with more 
confidence. When the door is opened and the curtain is pulled up you find all sorts of things. It is not correct to say that the social atmosphere is completely lacking but it is not what writers hope for ... Society has not yet been able to create an atmosphere that allows one to reflect freely; it hasn't yet been able to create the conditions that allow writers or artists to become not just tellers of stories or drawers of pictures but also intellectuals. They need to be free to reflect on the problems of society and of the country and to ponder the fate of people. Only then will they be able to think creatively. Creative thinking is what is most lacking in many works. One can blame writers but one must also ask why writers don't think creatively. Is it because they don't dare to think creatively, don't dare to reveal their thoughts? There has to be a particular kind of social atmosphere before people will become thinkers . . The main thing is to create an atmosphere that encourages debate. Only when we have an open and truly democratic atmosphere can we hope to see works of quality.

Certainly the social atmosphere restricts and wears down a writer's will and inspiration to create. The creative climate has become sluggish, exhausted, and disjointed and so the leanness, the mediocrity, of literature is an obvious result.

We need to analyze this more carefully, however. For a long time we have heard it said that we enjoyed an excellent renovation phase in literature because, as mentioned above, the strings restricting literature were "untied" [cởi trói $]{ }^{30}$ I don't completely agree. To speak in this way suggests that at that time someone of good will pitied literature and so untied the strings restricting it. The implication is that literature was lucky to be the recipient of such kindness. Actually that is not what happened. In these matters, as in Renovation generally, kindness, or good-heartedness [tốt lòng] was not a factor: No one was good-hearted and even if you had a good heart there was nothing you could have done. Renovation, as we know, began in agriculture. Farmers were dissatisfied with strict regulations; they were tired of being bound for a long time by unnecessary obstacles that were making it impossible for them to live their lives. So they untied themselves from these restrictions, at first illegally, "sneakily" [làm chui], which resulted in their being beaten down again and again. They were forced to pay a heavy price for their efforts but eventually they obtained the right to make changes openly and create conditions for new development. From agriculture the untying of restrictions spread to other economic areas, then to all aspects of society. Literature was part of this trend. It also untied itself in order to begin a process of self-renovation. Restrictions do not get untied without a struggle: It's not a matter of someone's good will. If literature has only been able to untie itself to a certain extent, if it has reached only a certain point on the road to Renovation before slowing down, then the primary cause lies within literature itself. 
Actually, during the past twenty years, since the benchmark year of 1991, writers have not remained completely silent; they have not been standing motionless on the sidelines. They have been stirring about in order to gradually mount another surprise attack. This is a matter that deserves careful attention and analysis.

Generally the short story has continued to be the most successful genre. One can mention the writers Phan Thị Vàng Anh, Phan Triều Hải, Bùi Hoằng Vị, and Ngô Khắc Tài; and more recently Nguyễn Ngọc Tư and Nguyễn Ngọc Thuần. As for novels, works by Nguyễn Xuân Khánh, Bùi Ngọc Tấn, Châu Diên, Nguyễn Việt Hà, Tạ Duy Anh, and Hồ Anh Thái deserve attention. In poetry the poets Vi Thùy Linh and Phan Huyền Thư.

Twenty years ago, Nguyễn Xuân Khánh wrote a novel that was banned as soon as it was printed: Region of Wild Imagination [Miền hoang tuoỏng]. His next novel, in which a farm for pig-raising is used as a metaphor for society, was not allowed to be published. He remained silent for twenty years. Recently many people were surprised when his thick and painstakingly written novel Hồ Quý Ly appeared. Written in a mature and solid style, one marked occasionally by some experiments in form (for example, the main character sometimes speaks in the first person, sometimes is referred to in the third person), this novel digs deeply into the tragedy of an historical character who lived at the beginning of the fifteenth century. ${ }^{31}$ Hồ Quý Ly was a talented and daring reformer who lived in a slow-moving, stagnant era and was forced to pay a painful price for his efforts. The people, the masses — whom particular conditions had turned into historical "reactionaries" [phản động]—opposed him and abandoned him when the invading forces arrived. The resistance that he initiated was not well-received. He and his son were captured and imprisoned by the enemy and died in ignominious exile. Of course, when someone reconstructs an historical tragedy in this way, it is always to suggest that it has some current relevance.

Story Told in the Year 2000 [Chuyện kể năm hai nghìn] by Bùi Ngọc Tấn ${ }^{32}$ enters "forbidden territory" [vùng cấm]. It is a story about a person who was unjustly imprisoned, locked up for no reason at all, or, more accurately, because of some conflicts somewhere or other that had nothing to do with the author, an extremely sincere, pure, and naive person caught up in a sinister social environment. The story is written in a "classical" [cổ điển] manner, no attempt is made to find a new style, but it is an interesting and convincing narrative. Bùi Ngọc Tấn moves beyond individual rancor and achieves an admirable calmness. In the midst of extreme suffering he remains humane and compassionate, always retaining a measured tone whether 
speaking about his own unparalleled capacity to quietly endure or about the cruelty he experienced, a cruelty all the more horrible because it was nameless or committed on behalf of some noble principle. Instead of simply describing an individual tragedy, or even a tragedy of the regime - a common focus of some books about prisons - he speaks about the absurdity of life. Without intending to he turns his work into a self-effacing but moving heroic poem about human beings, about their ability to endure the worst and darkest things, to rise above the dirt and the grime, all the while hanging tightly to their humanity, using it to oppose those dark powers that wish to take it from them. This book has been banned but in various ways it has reached many readers and its author enjoys the respect of the entire society. ${ }^{33}$

The Person of the River of Unconsciousness [Ngườ Sông Mê] by Châu Diên, ${ }^{34}$ which just appeared a few months ago, presents an unusual situation. It is the story of a person who has died, who should have crossed the River of Unconsciousness, eaten a bowl of forget porridge [cháo lú $],{ }^{35}$ and forgotten all worldly matters. Instead he is reincarnated and suddenly finds he has the ability to go back, to pass through different incarnations in order to tell stories about them. His previous lives take place in different contexts and include different characters. We encounter heroes and scoundrels and poetry and squalor. Goodness can be found but also plenty of cruelty. It is this view of society, as a mixture of these elements, that the author presents to readers. This work is Châu Diên's artistic experiment, his search for a different way to talk about both contemporary society and the history of Vietnam.

Tạ Duy Anh, the author of "The Broken Curse" [Bước qua lời nguyền], ${ }^{36}$ a work thought to have left its mark on the short story genre, is also the author of In Search of a Character [Đi tìm nhân vật,${ }^{37}$ a novel in which he appears to want to tear away the curtain covering the reality of everyday life and expose the anguished society that lies behind it. Hồ Anh Thái strives to capture modernity in The Place of the Doomsday Bell Ringer [Cõi ngườ rung chuông tận thê]. ${ }^{38}$ Nguyễn Việt Hà's The Lord's Opportunity [Co hội của Chúa $]^{39}$ is rather disorganized and loose but succeeds in evoking an atmosphere very much like the society of today, a society in which everything at times seems just as chaotic as the style of his novel. The author leaves the reader wondering where the truth lies.

Recently two young writers have received a great deal of attention from the public: Nguyễn Ngọc Tư in Cà Mau and Nguyễn Ngọc Thuần in Bình Thuận. These two voices from the provinces are strangely cheerful; they are like a cool breeze entering a literature that has long emphasized unwavering social engagement. Could it be that literature wants to return to a simple 
and pure kind of beauty? Nguyễn Ngọc Tư reminds one of Sơn Nam, not the current Sơn Nam but when he was both more sincere and more intellectual; and also younger, freer, more modern, and more self-confident. ${ }^{40}$ As for Nguyễn Ngọc Thuần, he makes us think of Antoine de SaintExupery in The Little Prince. There are those who worry about Nguyễn Ngọc Thuần: Could his endless dreaming mean he is too soft? (Two works by Nguyễn Ngọc Thuần, "Closing My Eyes and Opening the Window" [Vừa nhắm mắt vừa mở cửa sổ] and "An Eternity of Dreaming” [Một thiên nằm mộng"] ${ }^{41}$ are beautiful; they are like long poems written in prose.) The appearance of Nguyễn Ngọc Thuần and Nguyễn Ngọc Tư can be understood as literature’s “opposite reaction” [phản úng ngươc] to society: When reality is confused and disorderly people suddenly have a strong need to talk about dreams (or illusions?) that are pure and chaste.

In recent years, which have been quiet in some ways, deep in others, some memoirs by writers have appeared. Since the end of the war we have seen many memoirs of a type we can call "memoirs of the generals" [hồi ký của các vị tướng]—war stories by generals about their own experiences and those of soldiers in their units. Sometimes these memoirs provide a great deal of valuable historical material that official histories have overlooked. Memoirs by writers are different. In all societies writers help the society remember. They are the people whom society entrusts with the ongoing task of holding a mirror up to itself as it sets out on the road ahead. A writer's memoir is different because in it we hear society talking about itself (at least in a successful memoir). Two extremely noteworthy memoirs have been written by Tô Hoài: Dusty Sand on Somebody's Footsteps [Cát bụi chân ai] and Every Afternoon [Chiều chiều]. ${ }^{42}$ Tô Hoài has his own rules for living and writing. For years he has stepped forward and accepted a social project that on first hearing sounds very strange: to be a "team leader of city dwellers" [tổ trương dân phố]. ${ }^{43}$ It turns out that this has been the best possible vantage point for him, one that has allowed him patiently to observe society for an extended period of time. He writes very diligently, never missing a day. "I'm like a laborer," he says, "Everyday I'm chiseling and whittling." Everyday he is also recording society. His two memoirs (and no doubt there will be many more to follow) are like a straightforward and honest diary. They include commentary on society, on human beings, on the regime — on what turns out to be an entire era filled with turmoil and with a mixture of the tragic and the comic that is characteristic of Vietnamese society.

Nguyễn Khải's memoir God Is Laughing [Thượng đế thì cười] ${ }^{44}$ and Đào Xuân Quý's Remembering [Nhó lai $]^{45}$ have also received a lot of attention. As far as I know many other 
writers are working on their own memoirs. When a writer writes a memoir in a certain way that memoir is also a novel, a way of talking about one's own time. And for Vietnamese writers their "own time" is choc full of material.

Literature wants to become more multifaceted. People are searching for new ways of speaking that will reflect a social reality that day by day is becoming more and more complicated. A very important factor in this new search will be the level of energy and ability shown by young people because, of course, it is they who must take on this important work.

In this regard one phenomenon deserves some thought. If we look again at recent developments we notice something that is not completely normal: Almost all of the works generally agreed to have achieved a measure of success are by authors who belong to the "old guard" [đội cận vệ già], writers like Nguyễn Xuân Khánh, Bùi Ngọc Tấn, and Châu Diên. The artistic struggles of these writers are truly valuable, but if one reads carefully it is not difficult to discern in some of their attempts a rather forced quality; their efforts resemble "last gasps uttered as energy wanes" [một chút súc tàn]. Meanwhile some young writers have tried to break formal rules and find a new artistic voice, one capable of expressing a new artistic content. Their efforts are difficult to measure. For the past ten years or longer, not one new writer has stood out. And then there is another phenomenon: Some writers who were outstanding a few years back now appear to be "out of breath" [đưt hơi]. Nguyễn Huy Thiệp keeps repeating himself, even in short stories, a genre of which he has been the commanding general; and his experiments with the novel have clearly been failures. Bảo Ninh has been almost completely silent.

These developments suggest that our literature, because it lacks internal strength, may not prosper. One perhaps fundamental weakness, present in our literature for a long time, is now emerging clearly: The underlying cultural knowledge - understood in the broadest and deepest sense- of our writers is very shallow. This is the result of a decline in culture, which can be traced to failures in our system of education, failures which are being openly denounced by the public. Each day the outcry increases. The cultural knowledge of young writers nowadays is very low, and - even more worrisome - it is becoming lower with each succeeding generation. For a variety of reasons, Vietnamese literature has been cut off from world literature for many decades. Inside the country translation is in a sorry state. The translations produced are completely untrustworthy, the whole enterprise being adversely affected by market pressures. As a result of these factors, today's young writers are becoming more ignorant of foreign languages than their predecessors. 
Considering the social atmosphere and the state of literature itself, I don't think there is any basis for optimism. On the contrary, the situation leads us to this serious conclusion: In order to empower culture and literature we must implement - in an unyielding, long lasting, and thorough manner-a new "development" [khai hóa] project," a re-development. Only if we do this will we be able to go far.

\section{Translators' Notes to Introduction}

${ }^{1}$ This group of writers wrote under different names when they returned to their home regions. Nguyên Ngọc used the pen name Nguyễn Trung Thành. Others in this group, with their pen names in parentheses, are: Nguyễn Quang Sáng (Nguyễn Sáng), Lê Khâm (Phan Tứ), Bùi Đức Ái (Anh Đức), and Nguyễn Văn Bỗng (Trần Hiếu Minh).

${ }^{2}$ Nguyên Ngọc, Đất Nước Đứng Lên (Hà Nội: Văn Học, [1955]1959). For an English version see Nguyên Ngọc, The Village That Wouldn't Die, trans. by Trần Văn (Hanoi: Foreign Languages Publishing House, 1958).

${ }^{3}$ Nguyên Ngọc, Réo cao (Hà Nội: Văn Học, 1961); Nguyên Ngọc et al., Rù̀ng Xà nu (Hà Nội: Quân đội nhân dân, 1965). The title story from this latter collection is reprinted in Truyện ngắn miền nam [Short Stories from the Southern Region], ed. Giang Nam et al. (Hà Nội: Văn Học, 1966). For a translation of this story see Nguyên Ngọc, "The Forest of Xa Nu Trees," trans. by Mary Cowan et al., in Vietnamese Literature, eds. Nguyễn Khắc Viện and Hữu Ngọc (Hanoi: Foreign Languages Publishing House, 1983?), 898-913.

${ }^{4}$ We have had trouble finding a complete citation for this work. In an email message Nguyên Ngọc told us he wrote it in 1971 in the jungle and it was printed soon afterwards on a press carried down the Hồ Chí Minh trail. This press was carried on the shoulders of soldiers and it took three years to get it to the battlefield in central Vietnam. The People's Army Publishing House [Nhà Xuất Bản Quân Đội Nhân Dân] published it in the early 1970s but now, the author told us, even he doesn't have a copy of this edition (email message, November 14, 2007). In a recent article about Nguyên Ngọc in Văn Nghệ, Trần Đăng Khoa explains that Nguyên Ngọc planned to publish a second volume of Đất Quảng but burned the manuscript after learning that Phan Văn Giả, the person he planned to make the hero of that volume, had surrendered to the enemy. See "Nguyên Ngọc," http://www.viet-studies.info/TDKhoa_NguyenNgoc.htm (accessed November 7, 2007). Trần Đăng Khoa's essay appeared in Văn Nghệ 44 (November 3, 2007). In 
Cát Cháy [Burning Sand], a non-fiction work published after the war, Nguyên Ngọc also describes the fierce fighting in the Đà Nẵng area (HCMC: Trẻ, [1998?] 2002).

5 “Nguyên Ngọc," http://www.viet-studies.info/TDKhoa_NguyenNgoc.htm (accessed November 7, 2007). This essay appeared in Văn Nghệ 44 (November 3, 2007).

${ }^{6}$ Nguyên Ngọc, Nghĩ dọc đường [Thoughts along the Road] (HCMC: Văn Nghệ, 2006). An earlier Vietnamese version of this paper also appeared in Nhịp sống [Rhythm of Life] (2004) with the title "Văn xuôi Việt Nam hiện nay, logich quanh co cuẩ các thể loại, những vấn đề và triển vọng" [Vietnamese Prose Today: The Twisted Logic of the Genres, Problems and Prospects]. No volume or page numbers available. This journal is published in Boston by the Institute for Vietnamese Culture and Education.

${ }^{7}$ Tản mạn nhớ và quên [Scattered Thoughts Remembered and Forgotten] (HCMC: Văn Nghệ, 2005); Lắng nghe cuộc sống [Listening to Life] (HCMC: Văn Nghệ, 2006).

\section{Translators' Notes to "An Exciting Period for Vietnamese Prose"}

${ }^{8}$ In his only footnote, Nguyên Ngọc cites Roland Barthes' Writing Degree Zero (Paris: Seuil, 1953), a work that he has translated into Vietnamese. On the back page of a recent essay collection (Listening to Life [Lắng nghe cuộc sống]) (HCMC: Văn Nghệ, 2006)) the publisher indicates that Nguyên Ngọc has also translated works by Jean-Paul Sartre, Milan Kundera, and Jacques Dournes.

${ }^{9}$ In Nguyên Ngọc's references to the style of pre-renovation works as "epic" and in his emphasis on the dialogic quality of Renovation novels like Bảo Ninh's The Sorrow of War we see the clear influence of the Russian critic M. M. Bakhtin. Some scholars use the term "socialist realism" to refer to works by communist writers that promote and celebrate wartime heroism. In the West the term generally has negative connotations, suggesting dull works full of sunny optimism in which political persuasion, not literary quality, is the dominate objective. In the Socialist Republic of Vietnam, however, the term “social realism” [chủ nghĩa hiện thục xã họi] is still a valorized term, and so it is not surprising that Nguyên Ngọc does not use it in this context, preferring instead to speak of "the old war epic style" [lối viết cũ , lối viết sư thi trong chiến tranh]. But the term "sử thi" [epic], which literally means "history poem" in Vietnamese, is useful to the author for another reason. Bakhtin defines epic as a discourse that emphasizes a national past, not contemporary reality; that describes a collective national experience, not 
personal experience; and that is monologic (speaks in the unitary voice of authority), not dialogic (incorporates different voices, points of view). Bakhtin's conception of epic discourse therefore assists Nguyên Ngọc who wants "socialist realism," at least works that express "social reality," not, however, the old social reality of the war years but the new social reality of post-war Vietnam. See "Epic and Novel," in M.M. Baktin, The Dialogic Imagination, ed. Michael Holquist, trans. Caryl Emerson and Michael Holquist (Austin, TX: University of Texas Press, 1981), 4-40.

10 This story is included in Nguyễn Huy Thiệp, Tuoóng về hưu [The General Retires] (Hà Nội: Trẻ, 1988). This story has been translated into English. See "English Translations of Works by Writers Discussed by Nguyên Ngọc" in the appendix of this article.

${ }^{11}$ Trần Huy Quang, "Lồi khai của bị can” in Trần Huy Quang et al., Lời khai của bị can (Hạ Nội, Lâm Đông, Tuần báo Văn nghệ, Hội nhà văn Việt Nam hợp tác với Ban vận động thành lập Hội văn nghệ Lâm Đồng xuất bản, 1987), 5-23.

${ }^{12}$ Lưu Loan, "Người đàn bà quỳ" in Lưu Loan et al., Ngườ đàn bà quỳ (tập truyện—ký chọn lọc) Hà Nội: Nông nghiệp, Việt Nam, 1988), 16-31.

${ }^{13}$ Võ Văn Trực, “Tiếng kêu cứu của một vùng văn hóa,” in Lưu Loan et al., Người đàn bà quỳ (tập truyện—ký chọn lọc), 115-128.

${ }^{14}$ Hoang Hữu Các, "Đêm Trắng," in Lưu Loan et al., Ngườ đàn bà quỳ (tập truyện—ký chọn lọc), 129-145.

${ }^{15}$ Phung Gia Lộc, "Cái đêm hôm ấy đêm gì” in Lưu Loan et al., Ngườ đàn bà quỳ (tập truyệnký chọn lọc), 5-15.

${ }^{16}$ Nguyễn Mạnh Tuấn, Cù lao tràm (HCMC: Văn Nghệ, 1985).

${ }^{17}$ Nguyễn Khắc Trừong, Mảnh đất lắm nguời nhiều ma (Hà Nội: Hội Nhà Văn, 1991).

${ }^{18}$ Nguyên Ngọc indicates he is quoting the writer Nguyễn Khải but he does not cite a written source.

${ }^{19}$ Lê Lựu, Thời xa vắng [A Time Far Past] (Hà Nội: Hội Nhà Văn, 1984).

${ }^{20}$ Dương Hương, Bến không chồng [Wharf without a Husband] (HCMC: Hội Nhà Văn, 1991.

${ }^{21}$ Tạ Duy Anh, “Bước qua lời nguyền,” in Bước qua lời nguyền (Hà Nội: Văn Học, 1990), $137-$ 162.

${ }^{22}$ Hào Vũ, "Khách thương hồ" [The Floating Merchant] in Nhũng tâm hồn lạc [The Lost Souls] (n.p., Văn hóa Sài Gòn và First News ấn hành, 2007), 80-87. 
${ }^{23}$ Bakhtin speaks of refraction in his essay "Discourse in the Novel": "Heteroglossia [linguistic diversity, multiplicity of voices], once incorporated into the novel ..., is another's speech in another's language, serving to express authorial intentions but in a refracted way. Such speech constitutes a special type of double-voiced discourse. It serves two speakers at the same time and expresses simultaneously two different intentions: the direct intention of the character who is speaking, and the refracted intention of the author" [Bakhtin's italics] (The Dialogic Imagination, 324).

${ }^{24}$ This group includes the following trilogy of stories about Vietnamese characters and events from the late eighteenth century: "A Sharp Sword" [Kiếm sắc], "Fired Gold" [Vàng Lửa], and “Chastity” [Phẩm Tiết]. (Sometimes Nguyễn Huy Thiệp’s "A Drop of Blood” [Giọt máu] (included in the collection cited in note 10) is also categorized as a history story. In his trilogy, Nguyễn Huy Thiệp deals irreverently with the Vietnamese heroes Quang Trung and Nguyễn Du and has nice things to say about Gia Long, whom the current regime considers a reactionary. It is generally believed that Nguyên Ngọc was removed from his position as general editor of Literature and Art because he approved the publishing of these stories. All four history stories have been translated. See "English Translations of Works by Writers Discussed by Nguyên Ngọc" in the appendix.

${ }^{25}$ Bảo Ninh, Nỗi buồn chiến tranh [The Sorrow of War] (Hà Nội: Hội Nhà Văn, 1991). ${ }^{26}$ The Writers' Association convened a forum to discuss Bảo Ninh's controversial novel on August 24, 1991. Generally those attacking it accused the author of dwelling too much on the losses of the war and ignoring its glorious successes. For example, the critic Từ Sơn said that "the dominant impression the book leaves is of tragedy; the impression of heroism is buried — not treated sufficiently. Thus the tragic-heroic quality of the period that has passed is not rendered accurately." Nguyên Ngọc, who attended this forum, rose to defend Bảo Ninh's novel, arguing that it was about victory, "about the immense and formidable meaning and value of victory. It simply helps us understand how frightening was the cost of our glorious victory over the Americans." Remarks made at this forum were printed in Literature and Art. See "Thảo luận về tiểu thuyết Thân phận của tình yêu" [A Discussion of the Novel The Fate of Love (the original title of Bảo Ninh's novel)], Văn Nghệ 37 (14 September 1991): 6-7, 14.

${ }^{27}$ Here again (see notes 9 and 23) we see the influence of Bakhtin who contrasts the "unitary" language of the epic with the diversity of languages one finds in the novel. In its tendency toward monologue, Bakhtin argues, epic discourse reflects centripetal forces operating in 
language; in its dialogic quality, its incorporation of different voices - different social registers, dialects, jargons, etc.-novelistic discourse reflects centrifugal forces ("Discourse in the Novel," in The Dialogic Imagination, 259-422).

${ }^{28}$ This "general editor" was no other than Nguyên Ngọc himself who in 1988 was removed as editor and shifted to another position in the Writers' Association. It is generally believed that the cause of his dismissal was his publishing of some controversial stories by Nguyễn Huy Thiệp (see note 24). For press accounts of his dismissal, see K. C. Nguyen, "Left to Write," Far Eastern Economic Review 17 (August, 1989): 38; Murray Hiebert, “One Step Backward,” Far Eastern Economic Review (4 May 1989): 15; and Barry Wain, "Pitiful Writer Jolts Vietnamese Minds," The Asian Wall Street Journal (13 August 1990). For a retrospective look at these events, see the Phạm Đình Ân's interview with Ngô Ngọc Bội, an assistant to Nguyên Ngọc when he was general editor of Literature and Art: "Báo Văn nghệ những tháng ngày đầu đổi mới" [The Journal Literature and Art in the Early Days of Renovation], Talawas, http://www.talawas.org/talaDB/suche.php? res $=8991 \& r b=0102$ (accessed January 13, 2007). ${ }^{29}$ Tô Hoài, Cát bụi chân ai (Hà Nội: Hội Nhà Văn, 1992).

${ }^{30}$ Nguyên Ngọc is referring to a loosening of restrictions on writers and artists that occurred after Nguyễn Văn Linh, General Secretary of the Communist Party, met with a hundred writers and artists on October 7, 1987. The main topic of this meeting, convened soon after Renovation became official policy, was the disappointing state of the arts. Those attending spoke openly and boldly about the need for less government control of writers and artists. Responding to their demands, Secretary Nguyễn Văn Linh said: "You've talked a great deal about the need to 'untie the strings' to provide room for the full development of art and literature. Who's going to do this? I think the action must be initiated by the Party, which must 'untie the strings' in organization and in policies and regulations." This meeting, and Secretary Nguyễn Văn Linh's remarks, changed the atmosphere, emboldening editors to accept works by writers that they would have rejected earlier—works by writers like Nguyễn Huy Thiệp and Bảo Ninh, for example. Secretary Nguyễn Văn Linh's remarks and his exchanges with the writers and artists at the meeting were later printed in Văn Nghệ. See "Đồng chí tổng bí thư Nguyễn Văn Linh nói chuyện với văn nghệ sî” [General Secretary Nguyễn Văn Linh Talks with Writers and Artists], Văn Nghệ 42 (17 Oct. 1987), p. 3; and "Hai ngày đáng ghi nhớ mãi” [Two Days to Remember Forever], Văn Nghệ 42 (17 Oct. 1987, pp. 1-2, 14. For an English translation of Secretary 
Nguyễn Văn Linh's remarks, see “Let Writers and Artists Actively Contribute to Renovation,” Vietnamese Studies (New Series) 21 (1991): 117-125.

${ }^{31}$ Hồ Quý Ly (1336-1407?) distinguished himself by leading armed struggles against the Cham during the end of the Trần Dynasty. He took over the throne in 1400, then turned it over to his son, Hồ Hán Thương, the next year. Hồ Quý Ly is credited with pursuing some progressive policies including land reform but was opposed by powerful forces allied with the Trần. He also worked hard to improve the army and build fortifications to rebuff the Chinese who invaded Vietnam in 1406. His efforts, however, were unsuccessful and the Chinese of the Ming Dynasty occupied Vietnam until forces led by Lê Lợi forced them out in 1418. Hồ Quý Ly and his son were captured by the Chinese. Historians are not certain about the fate they suffered in the hands of their Chinese captors.

32 Bùi Ngọc Tấn, Chuyện kể năm hai nghìn [Story Told in the Year 2000] (Hà Nội: Thanh Niên, 2000).

${ }^{33}$ This book was confiscated soon after it was published by Thanh Niên Publishing House in 2000, but became available online. It was also published by Thời Mới Publishing House in Toronto, Canada, also in 2000.

${ }^{34}$ Châu Diên, Người Sông Mê (Hà Nội: Hội Nhà Văn, 2003).

35 "Cháo lú," or "forget porridge," is a porridge or gruel for ghosts in Hades who are about to be reincarnated. They eat it in order to forget their previous lives and their experiences in Hades. Also, when scolding someone whom one thinks is stupid, one can say he or she has eaten cháo $l u ́$.

${ }^{36}$ See note 21.

37 Tạ Duy Anh, Đi tìm Nhân vật [In Search of a Character] (Hà Nội: Văn Hóa Dân Tộc, 2002).

${ }^{38}$ Hồ Anh Thái, Cõi người rung chuông tận thế [The Place of the Doomsday Bell Ringer] (Đà Nẵng: Đà Nẵng Publishing House, 2003).

${ }^{39}$ Nguyễn Việt Hà, Co hội của Chúa (Hà Nội: Văn Học, 1999).

${ }^{40}$ Sơn Nam is an older writer who, like Nguyễn Ngọc Tư, is from south Vietnam. Born in Rạch Giá, now Kiên Giang Province, in 1926, he is best known for some short stories written in the mid and late 1950s that were later collected in Hương rùng Cà Mau [Fragrant Forests of Cà Mau] published in 1962. In a natural style that captures the flavor of southern speech, Son Nam vividly portrays life in the south when it was still in many respects a frontier region, a dangerous territory where tigers and crocodiles were a constant threat. Because both Nguyễn Ngọc Tư and 
Sơn Nam are from the south and both write about Cà Mau, Vietnam's southernmost province, it is not surprising that Nguyên Ngọc compares Nguyễn Ngọc Tư to this well-known older writer. ${ }^{41}$ Nguyễn Ngọc Thuần, "Vừa nhắm mắt vừa mở cửa sổ," in Nguyễn Ngọc Thuần--Cha và con và ... tàu bay [Nguyễn Ngọc Thuần—Father and Son and ... The Airplane] (Hà Nội: Hội Nhà Văn, 2006), 177-314; "Một thiên nằm mộng: (tiểu thuyết)" (Hà Nội: NXB Kim Đồng, 2006). ${ }^{42}$ Tô Hoài, Cát bụi chân ai (Hà Nội: Hội Nhà Văn, 1992); Chiều chiều (Hà Nội: Hội Nhà Văn, 1999).

${ }^{43}$ A "tổ trưởng dân phố" is the head of a group of households. Each precinct [phiờng] includes a number of streets and households along each street are divided into groups under a "leader of households" (tổ trương dân phố). This leader has various responsibilities. For example, he or she signs papers for couples planning to be married and collects money for candles and flowers if someone dies or for contributions to families with wounded or deceased soldiers on days when veterans are honored. Recently this position, which involves surveillance of, as well as assistance to, city dwellers has been weakened by a mass immigration of rural people to urban centers (Nguyễn Nguyệt Cầm, email to author, February 4, 2007).

${ }^{44}$ Nguyễn Khải, Thuoơng đế thì cuời (Hà Nội: Hội Nhà Văn, 2003).

${ }^{45}$ Đào Xuân Quý, Nhớ lại (Hà Nội: Văn hóa thông tin, 2002).

\section{Appendix: English Translations of Works by Writers Discussed by Nguyên Ngọc}

Bảo Ninh. The Sorrow of War [Nỗi buồn chiến tranh]. Translated by Phan Thanh Hao. Edited by Frank Palmos. New York: Riverhead Books, 1993.

Bùi Ngọc Tấn. "The Servants" [Nhũng ngườ đi ở]. Translated by Nguyen Huy Dzung and Wayne Karlin. In Love After War, edited by Wayne Karlin and Ho Anh Thai, 555-571. Willimantic, CT: Curbstone Press, 2003.

Hồ Anh Thái. Behind the Red Mist [Trong suơng hồng hiện ra]. Chief translator: Nguyen Qui Duc. Edited by Wayne Karlin. Willimantic, CT: Curbstone Press, 1998. . "Letters of Credence" [Lá quốc thu]. Translated by Ho Anh Thai and Wayne Karlin. In Love After War, edited by Wayne Karlin and Ho Anh Thai, 169-177. Willimantic, CT: Curbstone Press, 2003. 
. “A Short Rain” [Mây mưa mau tạnh]. Translated by Ho Anh Thai and Wayne Karlin.

In Love After War, edited by Wayne Karlin and Ho Anh Thai, 319-327. Willimantic, CT: Curbstone Press, 2003.

. The Women on the Island [Ngườ đàn bà trên đảo]. Translated by Phan Thanh Hao, Celeste Bacchi, and Wayne Karlin. Seattle: University of Washington Press, 2000.

Lê Lựu. A Time Far Past [Thời xa vắng]. Translated by Ngô Vĩnh Hải, Nguyễn Bá Chung, and

Kevin Bowen. Amherst, MA: University of Massachusetts Press, 1997.

Nguyễn Huy Thiệp. Crossing the River: Short Fiction by Nguyen Huy Thiep. Edited by Nguyen

Nguyet Cam and Dana Sachs. Translated by Bac Hoai Tran et al. Willimantic, CT:

Curbstone Press, 2003.

. The General Retires and Other Stories. Translated by Greg Lockhart. Singapore:

Oxford University Press, 1992.

Nguyễn Khải. Past Continuous [Thời gian của người]. Translated by Phan Thanh Hao and

Wayne Karlin. Willimantic, CT: Curbstone Press, 2001.

. "Sunlight at Dusk" [Nắng chiều]. Translated by Nam Son and Wayne Karlin. In Love After War, edited by Wayne Karlin and Ho Anh Thai, 541-554. Willimantic, CT:

Curbstone Press, 2003.

. “Those Days of Happpiness" [Đã từng có những ngày vui]. Translated by Nguyen Ba

Chung. In Writing Between the Lines, edited by Kevin Bowen and Bruce Weigl, 289-

295. Amherst, MA: University of Massachusetts Press, 1997.

Nguyễn Ngọc Tư. "The End of a Season of Beauty” [Cuối mùa nhan sắc]. Translated by Nam

Son and Wayne Karlin. In Love After War, edited by Wayne Karlin and Ho Anh Thai, 572-580. Willimantic, CT: Curbstone Press, 2003.

Phạm Thị Hoài. The Crystal Messenger [Thiên sú]. Translated by Ton That Quynh Du. South Melbourne: Hyland House, 1997.

. "Nine Down Makes Ten" [Chín bỏ làm mười]. Translated by Peter Zinoman. In Night, Again: Contemporary Fiction from Vietnam, edited by Linh Dinh, 75-86. New York: 7 Stories Press, 1996.

. "The Saigon Tailor Shop" [Tiệm May Sài Gòn]. Translated by Nguyen Qui Duc. In Love After War, edited by Wayne Karlin and Ho Anh Thai, 352-363. Willimantic, CT:

Curbstone Press, 2003. 
Phan Thị Vàng Anh. "Pantomime” [Kịch câm]. Translated by Nguyen Nguyet Cam. Manoa 7.2 (Winter, 1995): 109-111.

. "Thương." Translated by Nam Son and Wayne Karlin. In Love After War, edited by Wayne Karlin and Ho Anh Thai, 169-177. Willimantic, CT: Curbstone Press, 2003.

Phùng Gia Lộc, “The Night of That Day, What a Night!” [ Cái đêm hôm ấy đêm gì]. Translated by Birgit Hussfeld and Hans Schodder. Manoa 7.2 (Winter, 1995): 51-58.

Tạ Duy Anh. “The Broken Curse” [Bước qua lời nguyền]. Translated by Viviane Lowe. Manoa 7.2 (Winter, 1995): 142-156.

Tam Lang. I Pulled a Rickshaw [Tôi kéo xe]. In The Light of the Capital: Three Modern Vietnamese Classics, Translated by Greg Lockhart and Monique Lockhart, 51-120. Kuala Lumpur: Oxford University Press, 1996.

Tô Hoài. “Xuân Diệu's Love of Men” [Excerpt from Dusty Sand on Somebody's Footsteps [Cát bụi chân ai]. Translated by Nguyễn Quốc Vinh. Viet Nam Forum 16 (1997): 281-288.

Vũ Trọng Phụng. Dumb Luck [Số đỏ]. Translated by Nguyễn Nguyệt Cầm and Peter Zinoman. Edited by Peter Zinoman. Ann Arbor: University of Michigan Press, 2002. . Household Servants [Com thầy corm cô]. In The Light of the Capital: Three Modern Vietnamese Classics. Translated by Greg Lockhart and Monique Lockhart, 121156. Kuala Lumpur: Oxford University Press, 1996. 